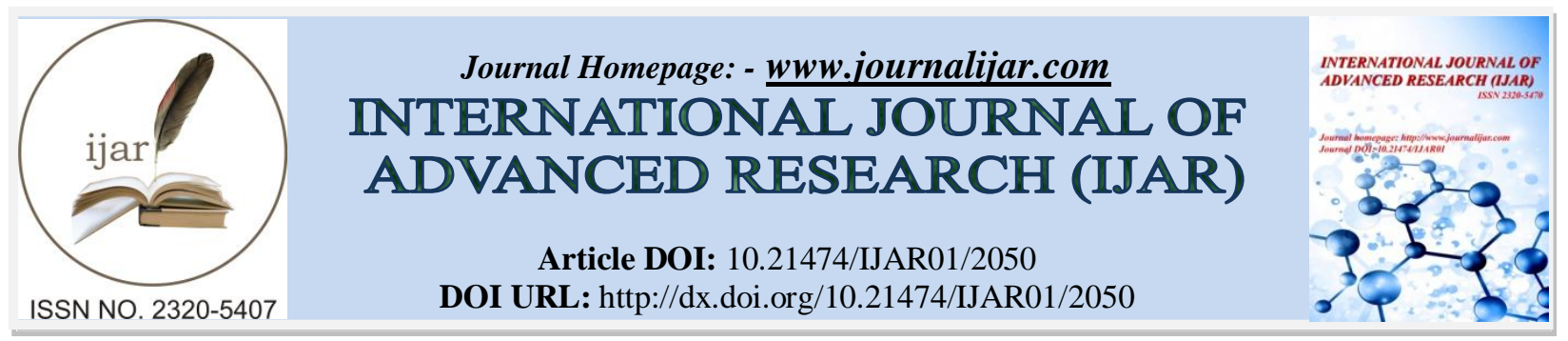

RESEARCH ARTICLE

\title{
EFFECTS OF ADMINISTRATION OF ETHANOLIC EXTRACT OF GANODERMA LUCIDUM ON ARTERIAL BLOOD PRESSURE OF NORMOTENSIVE CATS.
}

\author{
A.D.T. Gojii ${ }^{1}$, J.A. Tende ${ }^{2}$, D.S. Amaza ${ }^{3}$ and I. Ezekiel ${ }^{4}$. \\ 1. Department of Human Physiology, Faculty of Medicine, Kaduna State University, Nigeria. \\ 2. Department of Human Physiology, Faculty of Medicine, Ahmadu Bello University Zaria, Nigeria. \\ 3. Department of Anatomy, Faculty of Medicine, Kaduna State University, Nigeria. \\ 4. Department of Biological Sciences, Faculty of Pure and Applied Sciences, Federal University Wukari, Nigeria.
}

\section{Manuscript Info}

(.........................

Manuscript History

Received: 20 September 2016

Final Accepted: 22 October 2016

Published: November 2016

Key words:-

Ganoderma lucidum; fruiting bodies, normotensive, arterial blood pressure; Atropine, Ach, Propranolol.

\section{Abstract}

The fruiting bodies ethanol extact of Ganoderma lucidum of the family Ganodermataceae was evaluated for arterial blood pressures lowering effects in normotensive cats. The effects of each dose of extract on the arterial blood pressure (BP) of normotensive cats were studied. The extract exhibited a significant $(p<0.05)$ dose-dependent depression of blood pressure in normotensive cats between 1, 10 and $50 \mathrm{mg} / \mathrm{ml}$. It produces a decrease in systolic blood pressure $(p<0.05$ value). It also exhibited a decrease in diastolic pressure which was significant $(p<0.05)$ at all three doses. On mean arterial blood pressure (MABP), Ganoderma lucidum has a decreasing effect, which is statistically significant. The activities of the extract were comparable to that of other reference drugs: propranolol, Ach, and Atropine sulphate. The intravenous $\mathrm{LD}_{50}$ value of the extract was $12.89 \mathrm{mg} / \mathrm{kg}$ body weight in mice (MEDEP, 2008). The results obtained from the present studies supported the traditional claim that the plant is used in the management of hypertension in human.

Copy Right, IJAR, 2016,. All rights reserved.

\section{Introduction:-}

Ganoderma lucidium is a member of the family Ganodermataceae ,the kingdom of fungi, the division of Basidiomycota, the class of homobasidiomycetes, the order of aphyllophorales, and the genus of Ganoderma (Chang, 1999).

Ganoderma lucidum is a fungi that has potentially shown potency in its use by traditional herbalist, elites and emperors in Korea, Japan and china and even locally here in Nigeria (Ofodile et al., 2005). Mushrooms have a notable place in the folkore through the world and in the tradition of many culture (chang and Bushwell, 1996). The family of Ganodermataceae consists of a large group of tree fungi of the class polyporaceae, specifically the genus Ganoderma and other related genera. Ganoderma fungi are mainly found in tropical and subtropical areas; the typical species is Ganoderma lucidum (Fr.) Karst. It is called Ling Zhi or Reishi(Chinese), Mannentake(Japanese) and Tuwon biri(Hausa). It is seasonal and can be found growing alone or in group on decaying hardwood logs and stumps. At first, the caps are irregularly knobby or elongated,but by maturity more or less fan-shaped; with a shiny, varnished surface often roughly arranged into lump "Zones", red to reddish brown when mature; when young often with Zones of bright yellow and white toward the margin. The stem is sometimes absent, but more commonly 
present; $3-14 \mathrm{~cm}$ long up to $3 \mathrm{~cm}$ thick; twisted; equal or irregular; varnished and colored like the cap;often distinctively angled away from one side of the cap. The under side is cream colored and porous G. lucidum is commonly known as a medicinally- potent mushroom. It has been widely used in china and other oriented countries for hundreds of years for treatment of various diseases, includind cancer. This mushroom is reported to have various biological activities, such as anti- tumor anti-bacterial and anti-viral activities (Yoon et al., 1994; wang et al., 1997; El- Mekkawy et al., 1998; Eo et al., 2000). It was also reported to have an anti- inflammatory and liver protective effect in rats (Lin et al., 1993; Lin et al., 1995)

Some medicinal uses of Ganoderma lucidum includes anti-tumor, immunomodulatory, immunotherapeutic, antiinflammatory, antiviral, anti-parasitic, anti-fungal, antidiabetic, and hepatoprotective activities. It has also been found to inhibit platelet aggregation, and to lower blood pressure, cholesterol and blood sugar. Because of these properties, lingzhi has been regarded as blood pressure stabilizer, antioxidant, analgesic, a kidney and nerve tonic. It has been used in bronchitis prevention and in the treatment of high triglycerides, high blood pressure, hepatitis, allergies, chemotherapy support, HIV support, and even for fatigue and altitude sickness (Paterson, 2006). More recently, environment and culture media have been investigated with regards to the effect they have on the extracellular or intracellular bioactive components found in the mycelium of Ganoderma lucidum (Fang et al., 2002; Kim et al., 2002; Lee et al., 2004).

The present day study was aimed at evaluating the anti hypertensive activity of the plant in cats in order to support or refute the claims by traditional herbalists

\section{Materials and Methods:-}

Plant Material Identification:-

A sample of Gnaderma lucidum (fruiting body) was collected around Ahamdu Bello University Zaria in February, 2008. The plant was identified and authenticated by M. Musa of the herbarium section in the department of Biological Sciences, Ahmadu Bello University Zaria. A herbarium specimen was prepared and deposited there with a voucher number of 005

\section{Extraction of Plant Material:-}

The extraction of the fruiting body Ganoderma lucidum was carried out in the department of Pharmacognosy, Faculty of Pharmaceutical science, Ahmadu Bello University, Zaria. 500g of the fruiting body of Ganoderma lucidum was dried and weighed using a weighing balance. It was then pounded in to powdery form using a hammer mill. $300 \mathrm{~g}$ of the powdery Ganoderma lucidum was mounted on the soxhlet apparatus and extracted using 1litre of ethanol (95\%) to obtain a brown liquid. The extract is poured into an evaporating dish to evaporate it over a water bath to dryness at temperature range of 40-500c for 1 hour to obtain the crude extract. About $15 \mathrm{~g}$ of the crude extract was obtained.

\section{Experimental Animals:-}

The experimental animals, cat (male) weighing $1.262 \mathrm{~kg}$ and $2.300 \mathrm{~kg}$ was purchased in Samaru market in Zaria, Nigeria and was kept in the animal house of the department of Pharmacology and Clinical Pharmacy, Ahmadu Bello University, Zaria under normal physiological condition and room temperature for 3 days to acclimatize. Animal was given normal diet and water, but was deprived of food prior to the experiment at least for 10 hours.

\section{Acute Toxicity Study:-}

The method of Lorke (1980) was adopted and a total of 24 rats weighing 120-145g each were used for this study. The animals were fasted for $12 \mathrm{hrs}$ before the study, but were allowed water ad libitum. In the initial phase, four groups $(\mathrm{n}=3)$ were given normal saline as control group and 100, 1000, and 10,000 mg/kg of the extract intraperitoneally (i.p) for the remaining three groups respectively. The were then observed for $24 \mathrm{hrs}$ for signs of toxicity or deaths .In the final phase, another four groups $(n=3)$ were given normal saline, 2000,4000 and 8000 $\mathrm{mg} / \mathrm{kg}$ of the extract i.p for the remaining groups respectively and were observed for signs of toxicity or deaths The median lethal dose $\left(\mathrm{LD}_{50}\right)$ was calculated from the final phase.

\section{Test for hypotensive study:-}

The cats $(1.262 \mathrm{~kg}$ and $2.300 \mathrm{~kg})$ used were anaesthetized using thiopental sodium $45 \mathrm{mg} / \mathrm{kg}$. Complete anesthesia was obtained after about 45 minutes, and the cat was placed in a dorso-ventral position on a dissecting table which was previously heated electrically to maintain the body temperature of the animal. The femoral vein of the cat was 
then dissected and canulated (insertion of a small tube into the vein through which drugs are directly injected into the circulation). The neck region of the cat was the shaved with scissors and the carotid artery was canulated and connected to a pressure transducer and the pressure was raised by means of a syringe to the expected blood pressure of the animal. The arterial canula was connected to the recording microdynanometer. Injection of drugs and extract were made starting with physiological normal saline and the response obtained on UGO basile graph sheet. The experiment was repeated twice.

\section{Statistical Analysis:-}

Results were expressed as Mean \pm Standard Error of Mean (SEM). The data was statistically analyzed using the oneway ANOVA to determine whether the result were significantly different from those in the corresponding control group followed by turkey multiple test comparison. The results were statistically significant when $\mathrm{P}$ values are less than $0.05(\mathrm{p}<0.05)$ as described by Duncan et al (1977).

\section{Results:-}

The extract was found to have a significant $(\mathrm{p}<0.05)$ and dose-dependent hypotensive effect at doses of 1,10 and 50 $\mathrm{mg} / \mathrm{ml}$ as it decreases the systolic and diastolic blood pressure in normortensive cats (Table 1 and 2)The highest decrease displayed by the extract at a dose $50 \mathrm{mg} / \mathrm{ml}$ was comparable to that of normal saline $0.9 \mathrm{w} / \mathrm{v}$. All values obtained were significant $\mathrm{p}<0.05$ in comparison with the negative control.

The extract was also found to have little or no effect on the amplitude of the pulse pressure and a decreasing effect that was stastistically significant $(\mathrm{p}<0.05)$ on the MABP.

Table 1:- The systolic blood pressure after administration of normal saline, standard drug and various concentrations of Ganoderma lucidum extract.

\begin{tabular}{|c|c|c|c|c|c|c|}
\hline \multirow[t]{2}{*}{ S/NO } & \multirow{2}{*}{$\begin{array}{l}\text { Volume } \\
\text { administered } \\
(\mathrm{ml})\end{array}$} & $\begin{array}{l}\text { Normal saline } \\
0.9 w / v \text { (control) }\end{array}$ & $\begin{array}{l}\text { Extract } \\
1 \mathrm{mg} / \mathrm{ml}\end{array}$ & $\begin{array}{l}\text { Extract } \\
10 \mathrm{mg} / \mathrm{ml}\end{array}$ & $\begin{array}{l}\text { Extract } \\
50 \mathrm{mg} / \mathrm{ml}\end{array}$ & \multirow[b]{2}{*}{ P-value } \\
\hline & & $\begin{array}{l}\text { Means } \pm \\
\text { SEM }\end{array}$ & Means \pm SEM & $\begin{array}{l}\text { Means } \quad \pm \\
\text { SEM }\end{array}$ & $\begin{array}{l}\text { Means } \quad \pm \\
\text { SEM }\end{array}$ & \\
\hline 1 & 0.1 & $65.50+5.50$ & $69.50+5.50$ & $66.00+5.00$ & $51.50+4.50$ & $0.153^{\mathrm{ns}}$ \\
\hline 2 & 0.2 & $71.00 \pm 10.00$ & $74.50 \pm 9.50$ & $61.00 \pm 0.00$ & $53.00 \pm 1.00$ & $0.030^{\mathrm{a}}$ \\
\hline 3 & 0.4 & $71.50+10.50$ & $74.00+11.00$ & $57.50+0.50$ & $48.50+1.50$ & $0.015^{\mathrm{a}}$ \\
\hline 4 & 0.8 & $68.00 \pm 11.0$ & $73.00 \pm 10.00$ & $50.00+5.00$ & $44.00+4.00$ & $0.009^{\mathrm{a}}$ \\
\hline
\end{tabular}

$\mathrm{a}=$ statistically significant, $\mathrm{ns}=$ statistically not significant.

Ganoderma lucidum has a decreasing effect on the systolic blood pressure that is dose dependent at constant volume.

Table 2:- The diastolic blood pressure after administration of normal saline, standard drugs and various concentrations of Ganoderma lucidum extract.

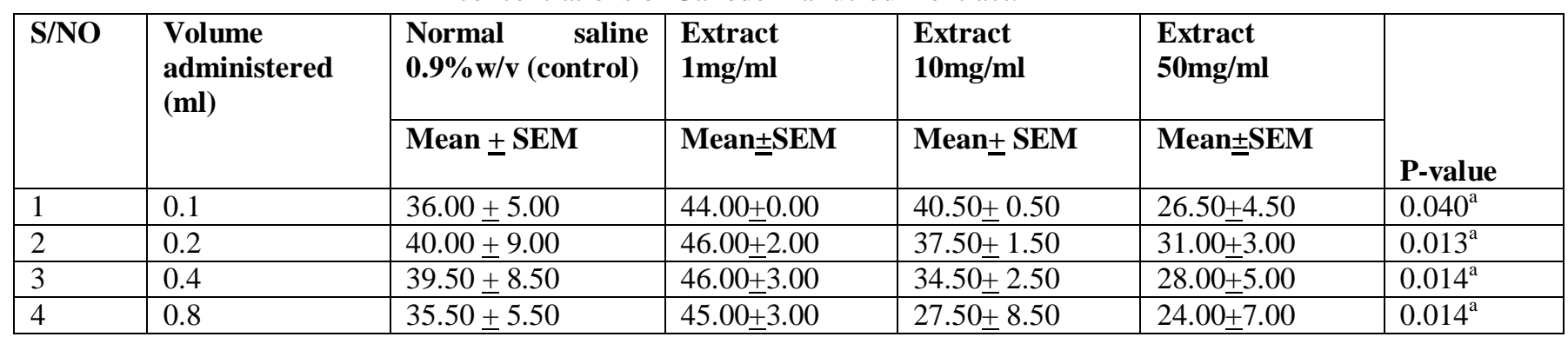

a=statistically significant, ns-statistically not insignificant.

Ganoderma lucidum has a decreasing effect on the diastolic blood pressure that is dose dependent at constant volume ( $<<0.005$ value). The change produced by Ganoderma lucidum at dose concentration $1 \mathrm{mg} / \mathrm{ml}, 10 \mathrm{mg} / \mathrm{ml}$ and $50 \mathrm{mg} / \mathrm{ml}$ are all statistically significant $(\mathrm{p}<0.05)$. 
Table 3:- The pulse pressure after administration of normal saline standard drugs and various concentrations of Ganoderma lucidum extract.

\begin{tabular}{|c|c|c|c|c|c|c|}
\hline \multirow[t]{2}{*}{ S/NO } & \multirow{2}{*}{$\begin{array}{l}\text { Volume } \\
\text { administered } \\
(\mathrm{ml})\end{array}$} & $\begin{array}{l}\text { Normal saline } \\
0.9 \mathrm{w} / \mathrm{v}\end{array}$ & $\begin{array}{l}\text { Extract } \\
1 \mathrm{mg} / \mathrm{ml}\end{array}$ & $\begin{array}{l}\text { Extract } \\
10 \mathrm{mg} / \mathrm{ml}\end{array}$ & $\begin{array}{l}\text { Extract } \\
50 \mathrm{mg} / \mathrm{ml}\end{array}$ & \multirow[b]{2}{*}{ P-value } \\
\hline & & Mean \pm SEM & Mean \pm SEM & Mean \pm SEM & Mean \pm SEM & \\
\hline 1 & 0.1 & $29.50 \pm 0.50$ & $25.50 \pm 5.50$ & $25.50 \pm 4.50$ & $25.25 \pm 0.25$ & $0.916^{\mathrm{ns}}$ \\
\hline 2 & 0.2 & $31.00 \pm 1.00$ & $28.50 \pm 7.50$ & $23.50 \pm 1.50$ & $22.00 \pm 2.00$ & $0.474^{\mathrm{ns}}$ \\
\hline 3 & 0.4 & $32.00 \pm 2.00$ & $28.00 \pm 8.00$ & $23.00 \pm 2.00$ & $20.50 \pm 3.50$ & $0.309^{\mathrm{ns}}$ \\
\hline 4 & 0.8 & $32.50 \pm 5.50$ & $28.00 \pm 7.00$ & $22.50 \pm 3.50$ & $20.00 \pm 3.00$ & $0.333^{\text {ns }}$ \\
\hline
\end{tabular}

$\mathrm{a}=$ statistically significant, $\mathrm{ns}=$ statistically not significant.

Ganoderma lucidum gas little or no effect on the amplitude of the pulse pressure. at volumes of $0.1 \mathrm{ml}, 0.2 \mathrm{ml}, 0.4 \mathrm{ml}$ and $0.8 \mathrm{ml}$. They produce changes in the pulse pressure that is statistically insignificant.

Table 4:- The mean arterial blood pressure of normal saline, standard drugs and various concentrations of

Ganoderma lucidum extract.

\begin{tabular}{|c|c|c|c|c|c|c|}
\hline \multirow[t]{3}{*}{ S/NO } & \multirow{3}{*}{$\begin{array}{l}\text { Volume } \\
\text { administered } \\
\text { (ml) }\end{array}$} & $\begin{array}{lr}\text { Normal saline } \\
0.9 \% \text { w/v (control) }\end{array}$ & $\begin{array}{l}\text { Extract } \\
1 \mathrm{mg} / \mathrm{ml}\end{array}$ & $\begin{array}{l}\text { Extract } \\
10 \mathrm{mg} / \mathrm{ml}\end{array}$ & $\begin{array}{l}\text { Extract } \\
50 \mathrm{mg} / \mathrm{ml} \\
\end{array}$ & \multirow[b]{3}{*}{ P-value } \\
\hline & & Mean \pm SEM & Mean \pm SEM & Mean \pm SEM & Mean \pm SEM & \\
\hline & & & & & & \\
\hline 1 & 0.1 & $45.85 \pm 5.15$ & $52.50 \pm 1.80$ & $49.00 \pm 2.00$ & $34.86 \pm 4.50$ & $0.061^{\mathrm{ns}}$ \\
\hline 2 & 0.2 & $50.35+9.35$ & $55.50 \pm 4.50$ & $45.30 \pm 1.00$ & $38.35 \pm 2.35$ & $0.016^{\mathrm{a}}$ \\
\hline 3 & 0.4 & $50.15 \pm 9.15$ & $55.35 \pm 5.65$ & $42.15 \pm 1.85$ & $34.85 \pm 3.85$ & $0.011^{\mathrm{a}}$ \\
\hline 4 & 0.8 & $46.35 \pm 7.35$ & $54.35+5.35$ & $35.00 \pm 7.30$ & $30.70 \pm 6.00$ & $0.010^{\mathrm{a}}$ \\
\hline
\end{tabular}

$\mathrm{a}=$ statistically significant, ns-statistically not significant

On mean arterial blood pressure (MABP), G. lucidum has a decreasing effect, that is statistically $(\mathrm{p}<0.05)$

significant at volumes of $0.2 \mathrm{ml}, 0.4 \mathrm{ml}, 0.8 \mathrm{ml}$

Result of drug antagonistic studies on Ganoderma lucidum extract:-

Table 5:- Interactions of $0.8 \mathrm{ml}$ extract $10 \mathrm{mg} / \mathrm{ml}$ with standard drugs showing systolic, diastolic, pulse and mean arterial blood pressure

\begin{tabular}{|c|c|c|c|c|c|}
\hline \multirow[t]{3}{*}{ S/No } & \multirow{3}{*}{$\begin{array}{l}\text { Blood } \\
\text { pressure } \\
(\mathrm{mmHg})\end{array}$} & \multicolumn{2}{|c|}{$\begin{array}{l}\text { 0.2ml Propranolol } 4 \mathrm{mg} / \mathrm{ml} \\
+0.8 \mathrm{ml} \text { extract } 10 \mathrm{mg} / \mathrm{ml}\end{array}$} & \multicolumn{2}{|c|}{$\begin{array}{l}\text { 0.2 } \mathrm{ml} \text { atropine } 100 \mathrm{ug} / \mathrm{ml} \\
+0.8 \mathrm{ml} \text { extract } 10 \mathrm{mg} / \mathrm{ml}\end{array}$} \\
\hline & & \multicolumn{2}{|c|}{ MEANS+SEM } & \multicolumn{2}{|c|}{ MEANS+SEM } \\
\hline & & Before & After & Before & After \\
\hline 1.0 & Systolic & $60.50+10.50$ & $48.00+6.00^{\mathrm{ns}}$ & $58.50+7.50$ & $50.00+5.00^{\mathrm{ns}}$ \\
\hline 2.0 & Diastolic & $40.50 \pm 8.50$ & $26.50 \pm 0.50^{\mathrm{ns}}$ & $35.00 \pm 5.00$ & $25.00 \pm 3.50^{\mathrm{ns}}$ \\
\hline 3.0 & Pulse & $20.00+2.00$ & $21.50 \pm 5.50^{\mathrm{ns}}$ & $23.50+2.50$ & $24.50 \pm 1.50^{\mathrm{ns}}$ \\
\hline 4.0 & Mean Arterial & $47.15+9.15$ & $33.65 \pm 2.35^{\mathrm{ns}}$ & $42.85+5.85$ & $33.70 \pm 4.00^{\mathrm{ns}}$ \\
\hline
\end{tabular}

$\mathrm{a}=$ statistically significant, $\mathrm{ns}=$ statistically not significant.

\section{Discussions:-}

The fruiting body ethanol extract of Gonaderma lucicum had demonstrated a significant $(\mathrm{p}<0.05)$ and dosedependant hypotensive activity. This was evident as it reduces systolic, diastolic, pulse and mean arterial blood pressure parameters significantly.

From the results, normal saline $0.9 \% \mathrm{w} / \mathrm{v}$ was used as the control, while the standard drug used are Acetylcholine $(1 \mu \mathrm{g} / \mathrm{ml})$, Propranolol $(4 \mathrm{mg} / \mathrm{ml})$ and Atropine $(100 \mu \mathrm{g} / \mathrm{ml})$. This was then used in the experiment to compare with the extract which is the ethanolic extract of Ganoderma lucidum of dose concentrations, $1 \mathrm{mg} / \mathrm{ml}, 10 \mathrm{mg} / \mathrm{ml} \mathrm{and}$ $50 \mathrm{mg} / \mathrm{ml}$ respectively.

From the tables above Ganoderma lucidum has a decreasing effect on the systolic blood pressure that is dose dependent and statistically significant, at constant volume, Ganoderma lucidum causes a decrease in the systolic 
blood pressure that is dose- dependent. It produces a decrease in systolic blood pressure as low as $69.50 \pm 5.5 \mathrm{mmHg}$, $50.00 \pm 5.00 \mathrm{mmHg}$ and $44.00 \pm 4.00 \mathrm{mmHg}$ at concentration of $1 \mathrm{mg} / \mathrm{ml}, 10 \mathrm{mg} / \mathrm{ml}$ and $50 \mathrm{mg} / \mathrm{ml} \mathrm{of} \mathrm{Ganoderma}$ lucidum extract respectively compared with $65.50 \pm 5.50 \mathrm{mmHg}$ for normal saline $0.9 \% \mathrm{w} / \mathrm{v}$ (p value), but this effect is lower than the effect produced by $0.8 \mathrm{ml}$ acetylcholine $(1 \mu \mathrm{g} / \mathrm{ml}), 38.50 \pm 4.50 \mathrm{mmHg}$.

Ganoderma lucidum has a high statistically significant decreasing effect on the diastolic blood pressure that is dose dependent at constant volume (P-value). Producing as low as $44.00 \pm 0.00 \mathrm{mmHg}, 27.50 \pm 8.50 \mathrm{mmHg}$ and $24.00 \pm 7.00 \mathrm{mmHg}$ for concentrations of $1 \mathrm{mg} / \mathrm{ml}, 10 \mathrm{mg} / \mathrm{ml}$ and $50 \mathrm{mg} / \mathrm{ml}$ respectively as against $35.50 \pm \mathrm{mmHg}$ produced by normal saline $0.9 \% \mathrm{w} / \mathrm{v}$. this blood pressure lowering effect is lower than that produced by $0.4 \mathrm{ml}$ acetylcholine $(1 \mu \mathrm{g} / \mathrm{ml}) 11.50 \pm 8.50 \mathrm{mmHg}$.

Ganoderma lucidum has little or no effect on the amplitude of the pulse pressure. The difference produced by different concentrations of Ganoderma lucidum $(1 \mathrm{mg} / \mathrm{ml}, 10 \mathrm{mg} / \mathrm{ml}$, and $50 \mathrm{mg} / \mathrm{ml})$ is statistically insignificant. On mean arterial blood pressure (MABP), Ganoderma Lucidum has a decreasing effect that is statistically significant. For example, the effect produced at volume $0.1 \mathrm{ml}$ of extract dose concentration of $1 \mathrm{mg} / \mathrm{ml}, 10 \mathrm{mg} / \mathrm{ml} \mathrm{and} 50 \mathrm{mg} / \mathrm{ml}$ are $25.50 \pm 5.00 \mathrm{mmHg}, 25.50 \pm 4.50 \mathrm{mmHg}$ and $25.50 \pm 0.25 \mathrm{mmHg}$ respectively compared to that of normal saline $0.9 \% \mathrm{w} / \mathrm{v}, 29.50 \pm 0.5 \mathrm{mmHg}$.

From the table above, the hypotensive effect of $0.8 \mathrm{ml}$ Ganoderma lucidum $10 \mathrm{mg} / \mathrm{ml}$ is blocked by $0.2 \mathrm{ml}$ atropine $100 \mu \mathrm{g} / \mathrm{ml}$. The effects are prominent on the systolic, diastolic and mean arterial blood pressure but not prominent on the pulse pressure. $0.2 \mathrm{ml}$ Propranolol $4 \mathrm{mg} / \mathrm{ml}$ partially blocked the activities of the $0.8 \mathrm{ml}$ Ganoderma lucidum extract $10 \mathrm{mg} / \mathrm{ml}$, but this is statistically insignificant.

However, the blockade produced by both atropine and Propranolol are said to be statistically insignificant, but the change that occurred with this two drugs are not great enough to exclude the possibility that the difference is due to chance.

This work is in consonant with the work of Lee et al. (1990) whose work suggests that the mycelium extract from Ganoderma lucidum inhibited sympathetic outflow and concluded that this was responsible for the hypotensive effect. Morigwa et al. (1986) demonstrated that a 70\% methyl alcohol extract of Ganoderma lucidum inhibited angiotensin-converting enzyme. This would limit blood pressure by blocking the rennin-angiotensin. Kabir et al studied the effect of a powder prepared from the culture fruit body of Ganoderma lucidum on the blood on the blood pressure of spontaneously hypertensive rat. After a 4-week feeding period, the systolic blood pressures of the rat significantly lower than the control, indicating that the powder contained a substance that suppresses the elevation of blood pressure.

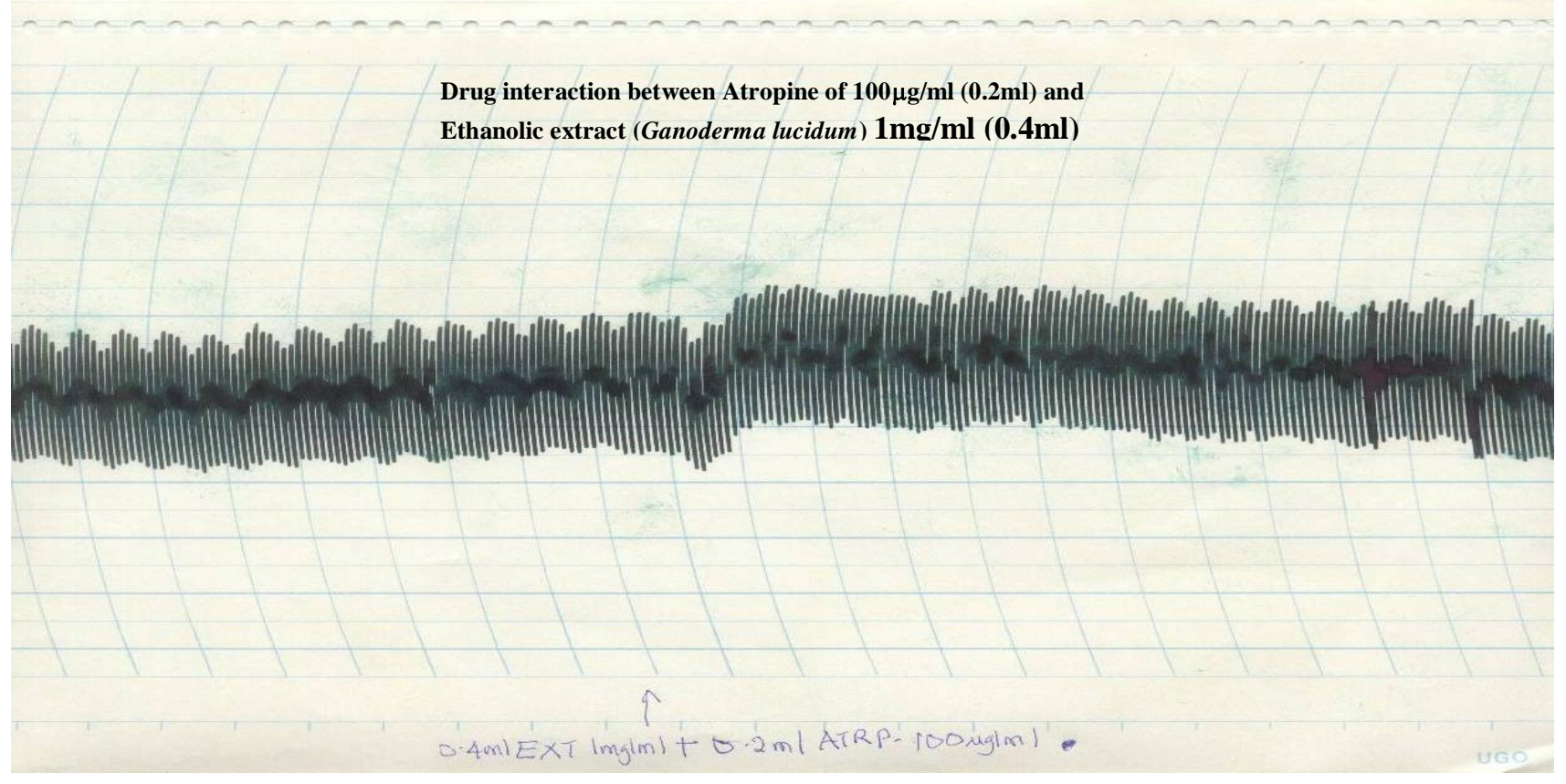


Drug interaction between Propranolol of $4 \mathrm{mg} / \mathrm{ml}(0.2 \mathrm{ml})$ and Ethanolic extract (Ganoderma lucidum) 1mg/ml (0.4ml)

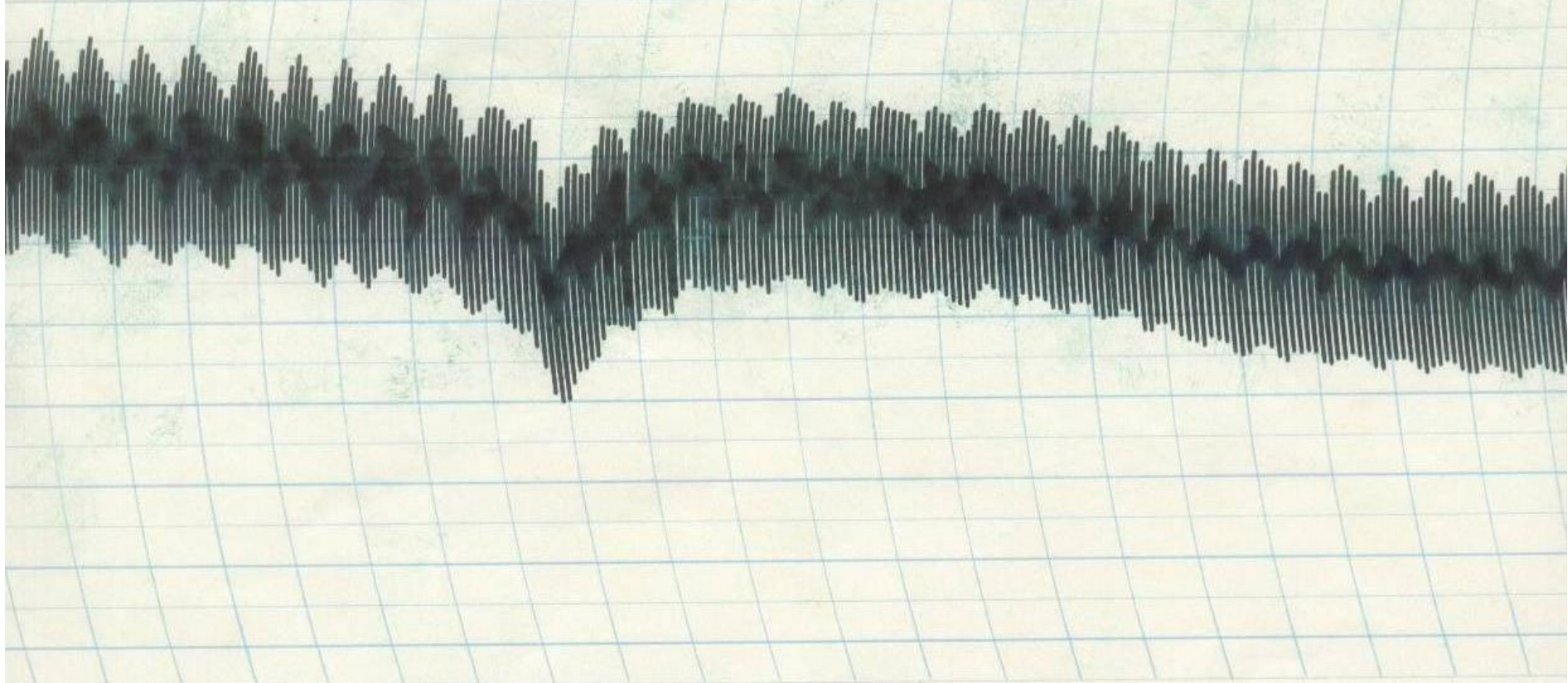

$$
\text { 0.4ml EXT. Imglmit v.2ml PROP. } 4 m g|m| \text {. }
$$

Ethanolic extract (Ganoderma lucidum) $50 \mathrm{mg} / \mathrm{ml}$ Volume $0.4 \mathrm{ml}$

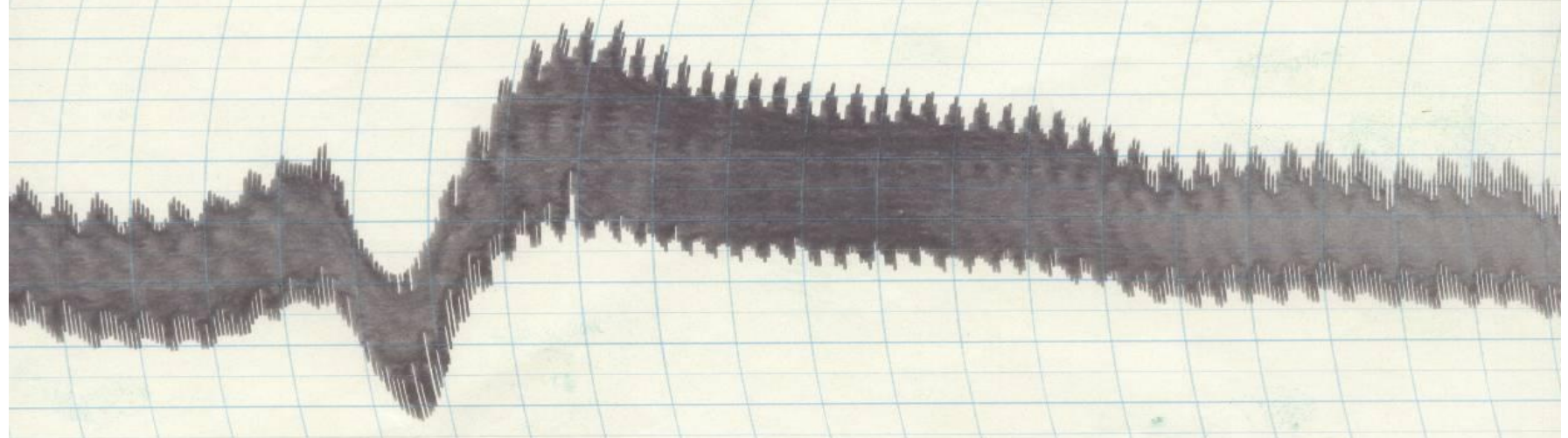



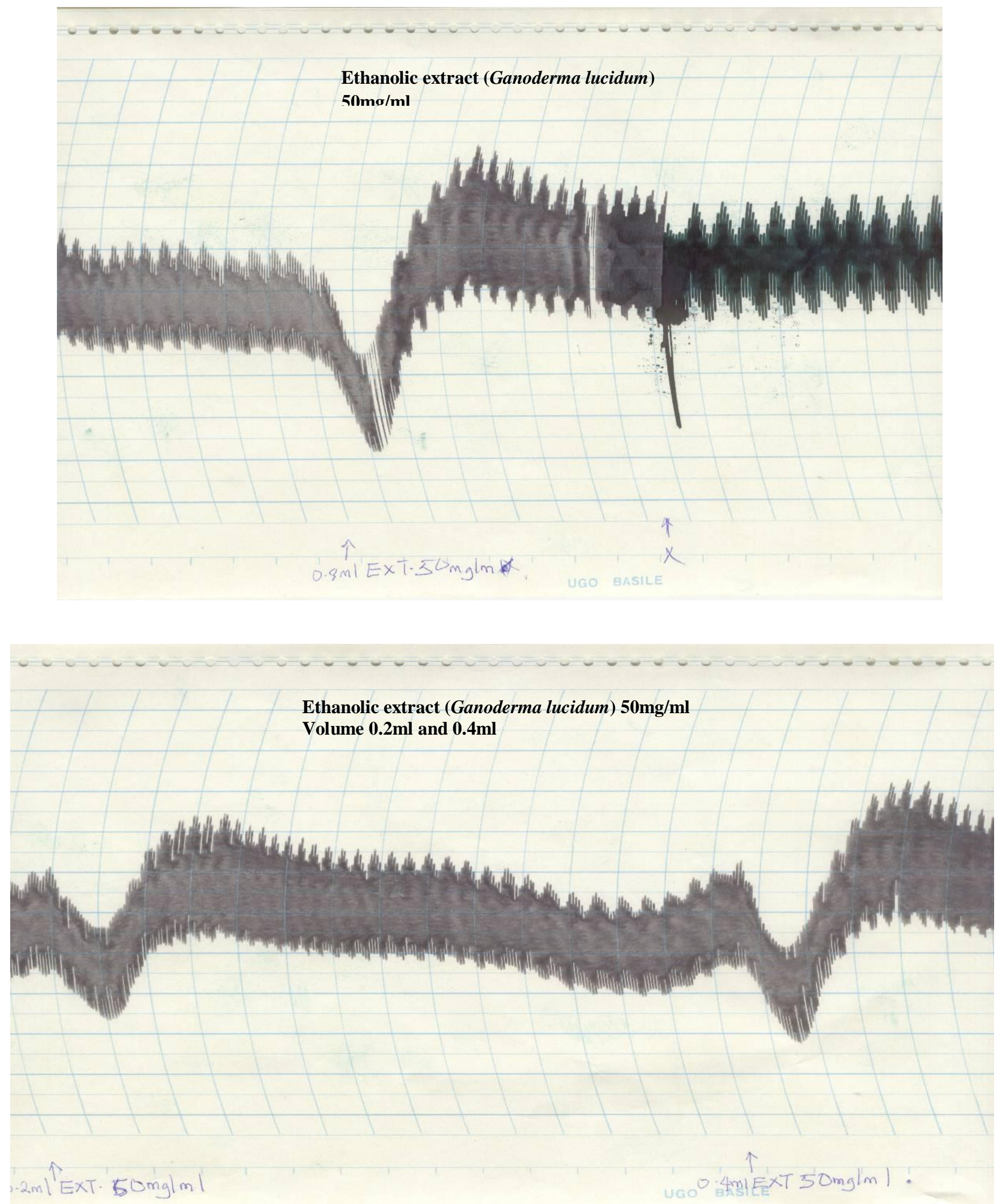


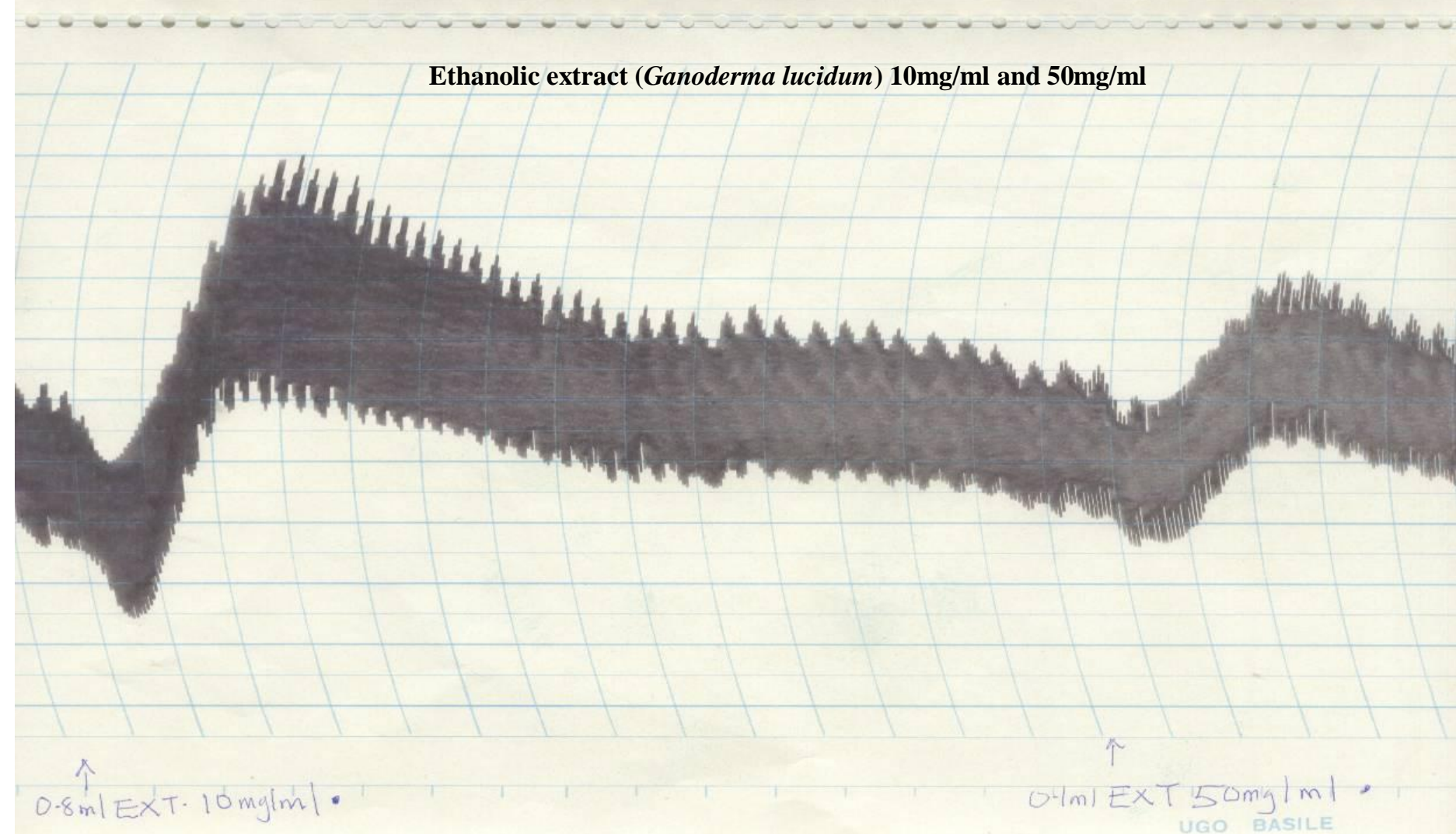

\section{Ethanolic extract (Ganoderma lucidum) $1 \mathrm{mg} / \mathrm{ml}$} Volume 0.4ml

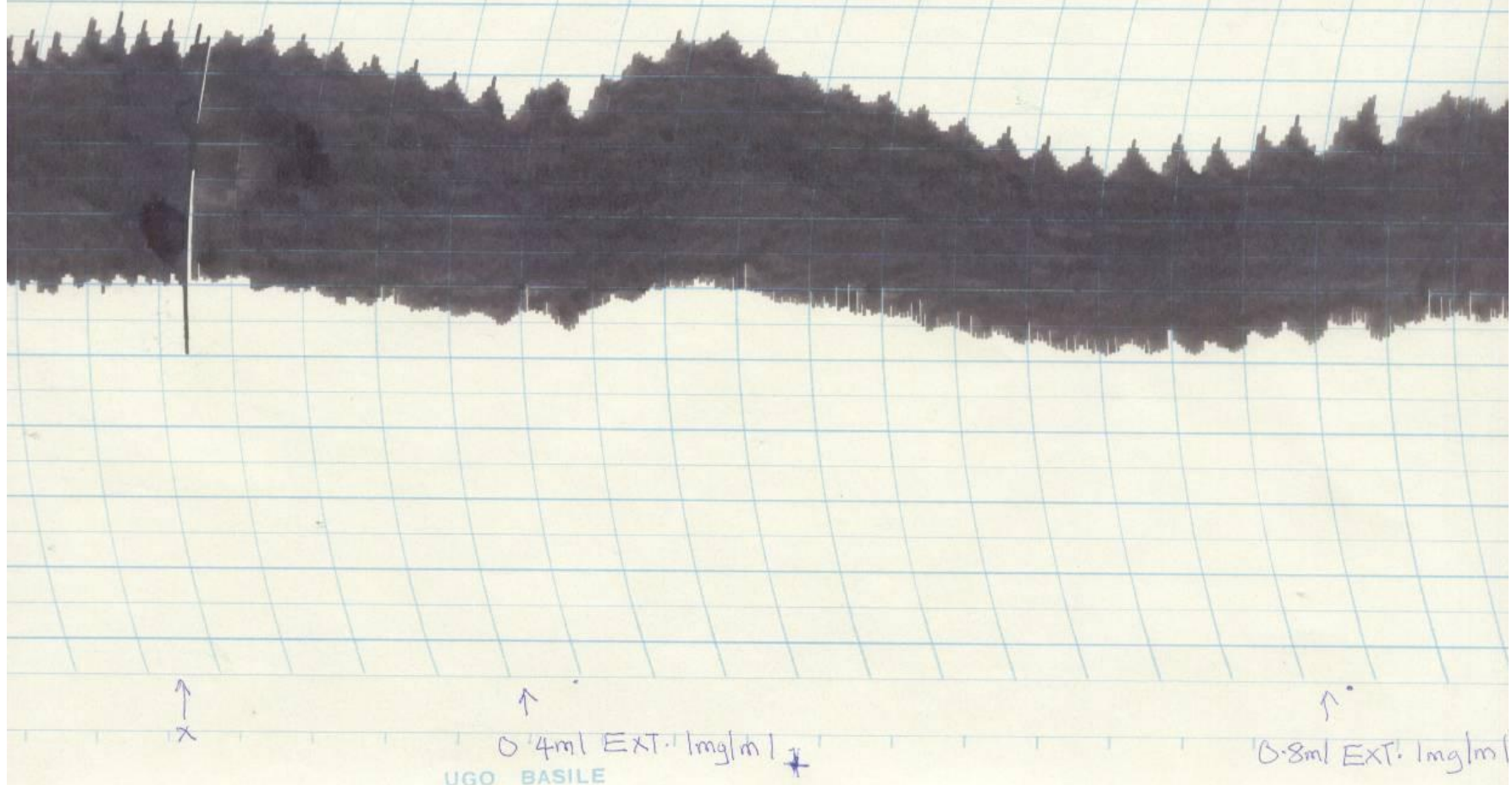



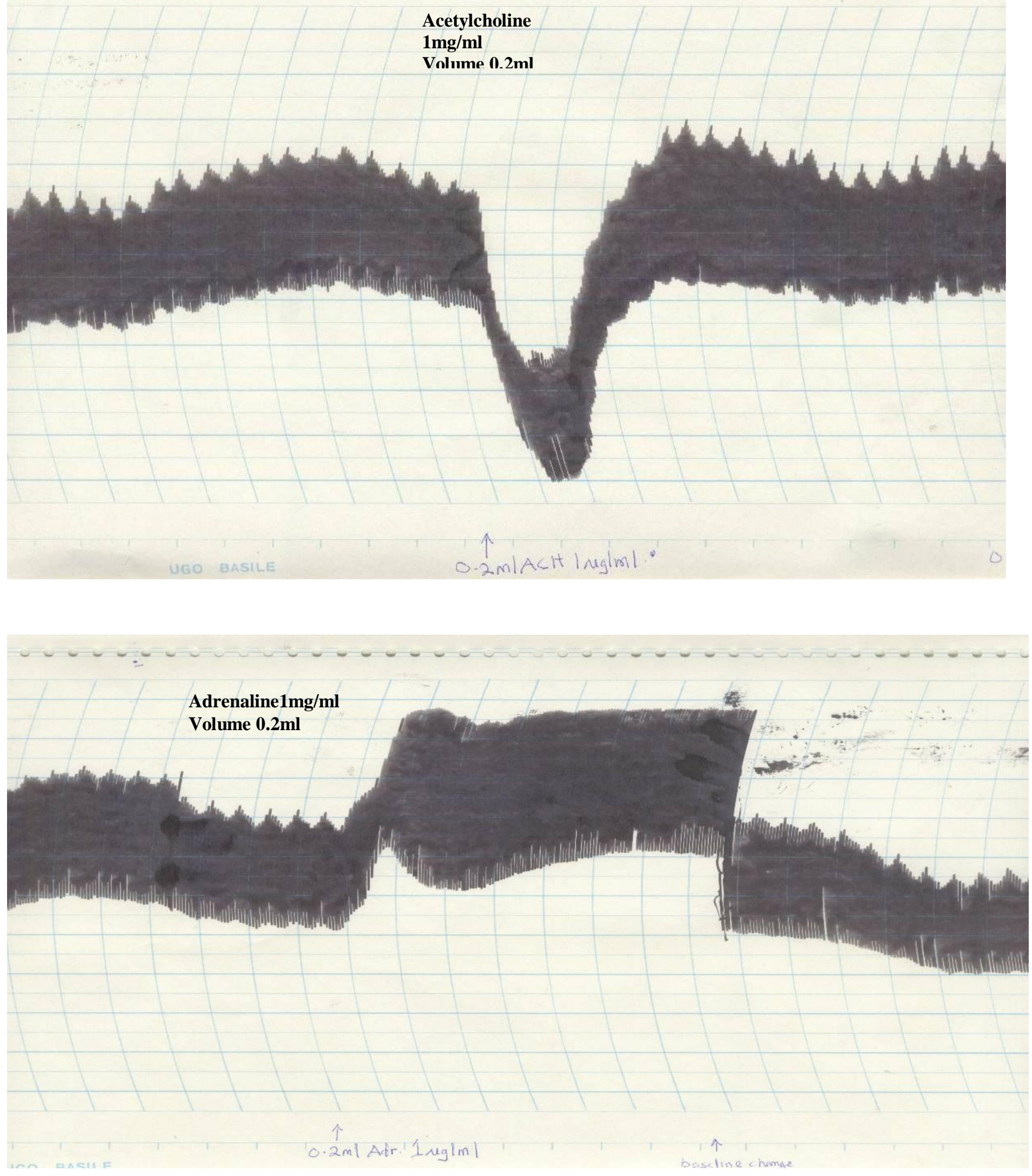
Normal saline $0.9 \% \mathrm{w} / \mathrm{v}$

Volume $0.2 \mathrm{ml}$ and $.4 \mathrm{ml}$

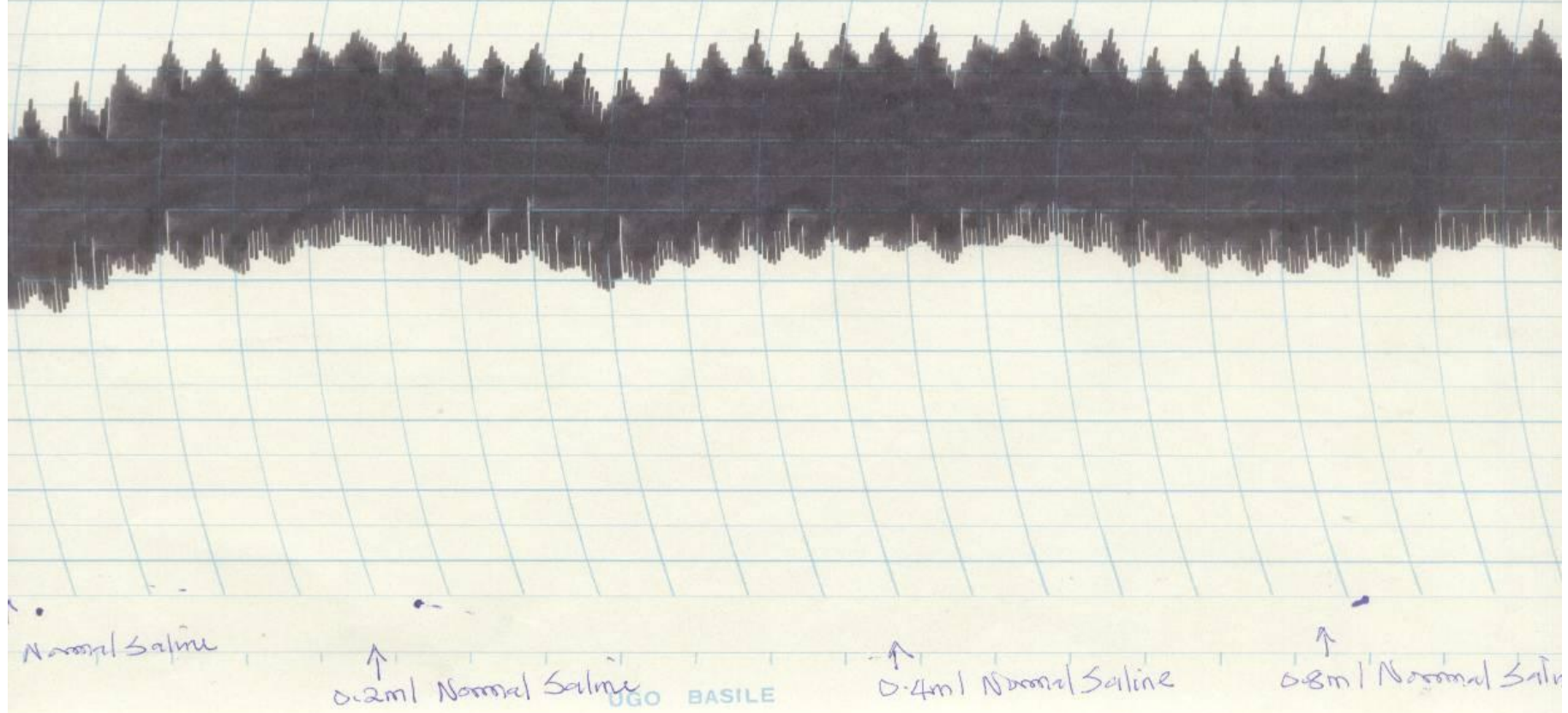

Drug interaction between Acetylcholine of $1 \mu \mathrm{g} / \mathrm{ml}(0.2 \mathrm{ml})$ and Ethanolic extract (Ganoderma lucidum) $1 \mathrm{mg} / \mathrm{ml}$

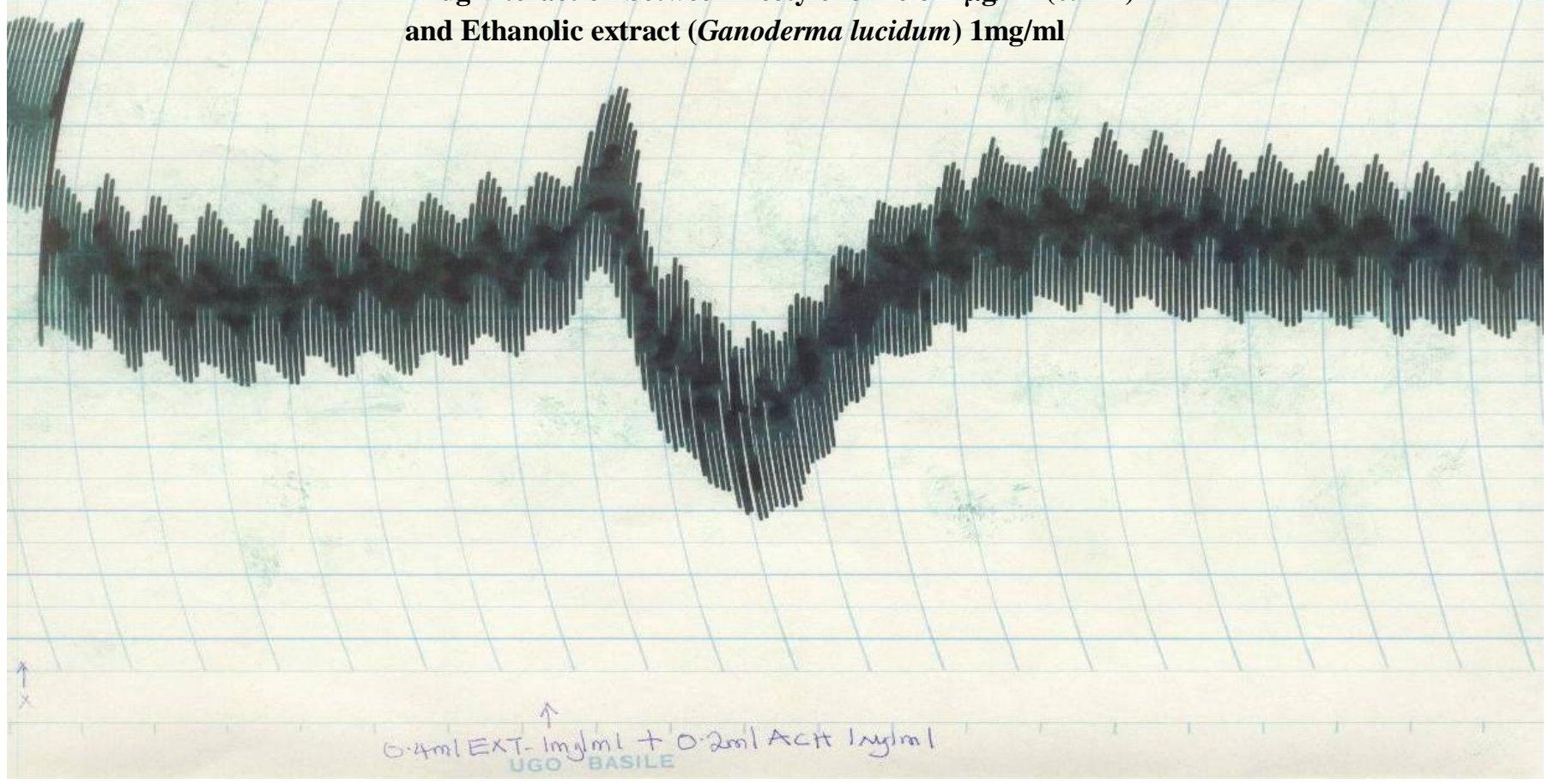



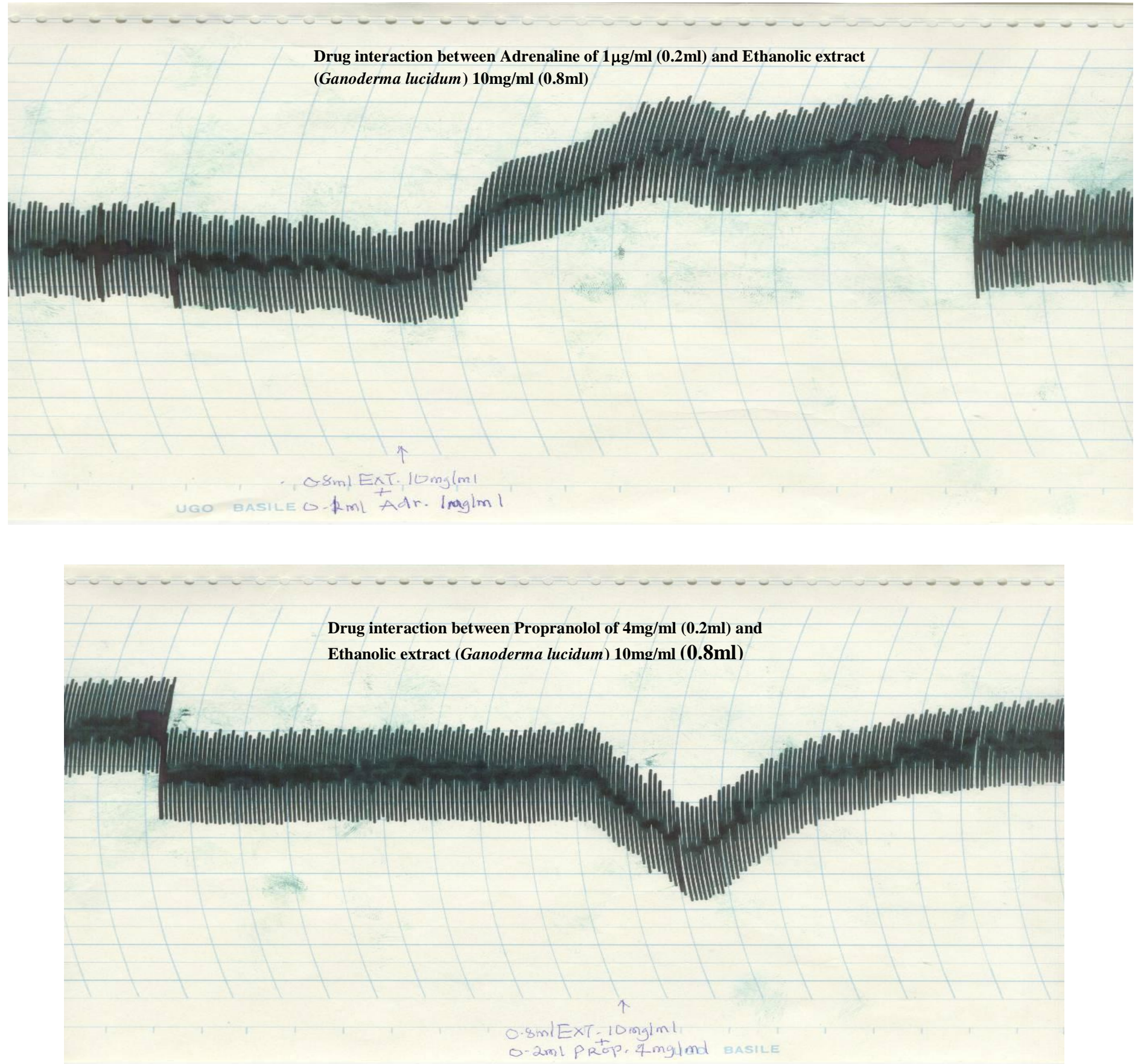
Drug interaction between Atropine of $100 \mu \mathrm{g} / \mathrm{ml}$

$(0.8 \mathrm{ml})$ and Ethanolic extract (Ganoderma lucidum)

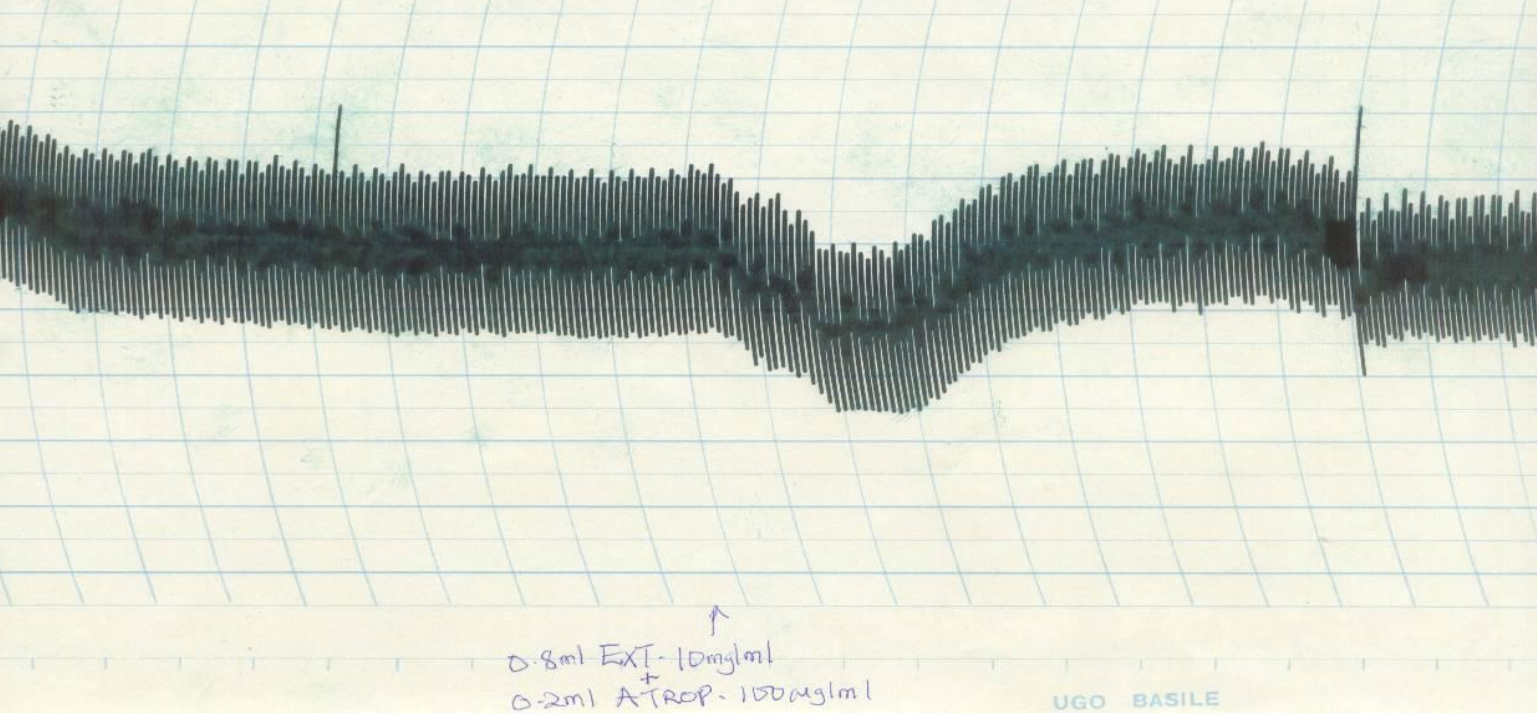

Drug interaction between Propranolol of $4 \mathrm{mg} / \mathrm{ml}(0.2 \mathrm{ml})$ and Ethanolic extract (Ganoderma lucidum) $1 \mathrm{mg} / \mathrm{ml}(0.4 \mathrm{ml})$

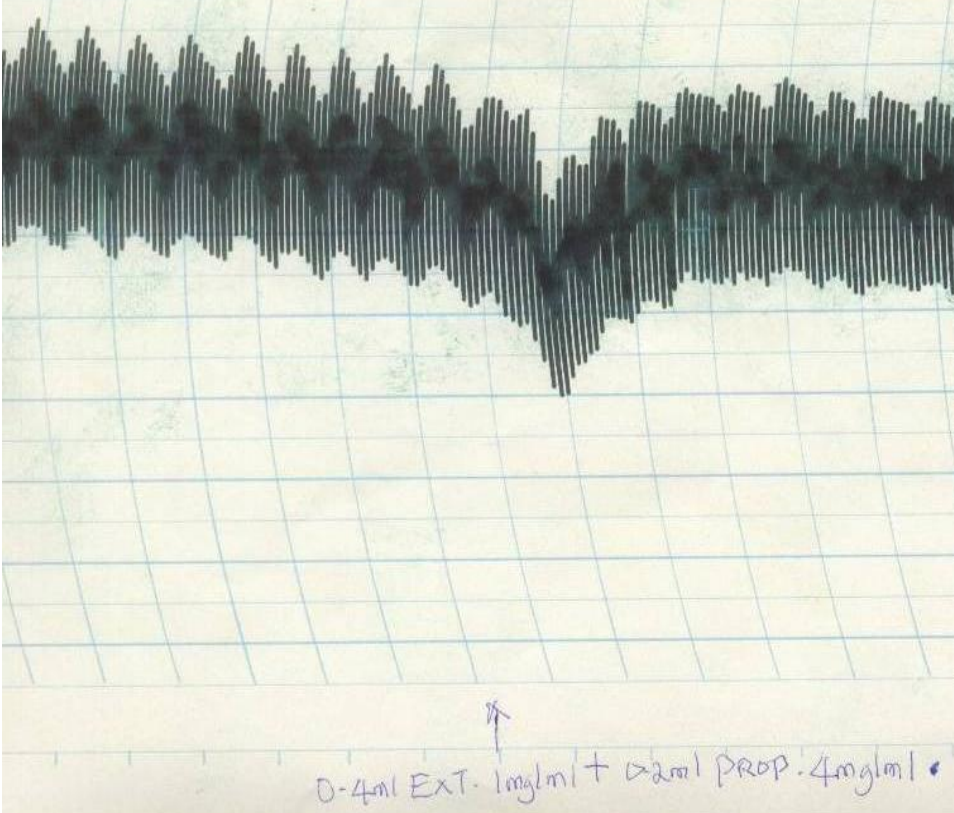




\section{Conclusion:-}

The fruiting body ethanol extract of Ganoderma lucidum of the Ganodermataceae family was found to have demonstrated a significant $(\mathrm{p}<0.05)$ and dose- dependant hypotensive activity at doses of 1,10 and $50 \mathrm{ml} / \mathrm{kg}$ respectively normal arterial blood pressure in healthy subject.

\section{References:-}

1. Chang, S.T. and Buswell, J.A. (1999): Ganoderma lucidum (Curt.: Fr.) P. Karst.

2. (Aphyllophoromycetideae) - a mushrooming medicinal mushroom.Int. J. Med. Mushrooms, 1 (2): 139-146.

3. Eo, S.K., Kim, Y.S., Lee, C.K. and Han, S.S. (2000): Possible mode of antiviral activity of Acidic protein bound polysaccharide isolated from Ganoderma lucidum on herpes simplex viruses. J. Ethnopharmacol. 72(3):475-481

4. Fang Q.H., J.J. Zhong (2002): Submerged fermentation of higher fungus Ganodermalucidum.For production of valuable bioactive metabolites-ganoderic acid and polysaccharide, Biochem. Eng. J. 10: 61-65

5. Gao, J.J., Min, B.S., Ahn, E.M., Nakamura, N., Lee, H.K., Hattori, M.(2002): NewTriterpene aldehydes, lucialdehydes A-C, from Ganoderma lucidum and their cytotoxicity against murine and human tumor cells. Chem. Pharm. Bull. (Tokyo) 50, 837-840

6. Kabir, Y, Kimura, S. And Tamura, T (1998): Dietary effect of Ganoderma lucidum on blood pressure and lipid level . Journal of Nutritional Science and vitaminology 43(4): 433-438.

7. Kim, Y.S., Eo, S.K., Oh, K.W., Lee, C. And Han, S.S. (2000): Antiherpetic activities of Acidic protein bound polysaccharide isolated from Ganoderma lucidum alone and in Combinations with interferons, $\mathbf{J}$ Ethnopharmacol, 72: 451-8

8. Lee D.H., Kim J.H., Park J.S., Choi Y.J. \& Lee J.S. (2004): Isolation and Characterization of a novel angiotensin I-converting enzyme inhibitory peptide Derived from the edible mushroom Tricholoma giganteum. Peptides 25(4): 621-627.

9. Lei, L.S., Lin, Z.B., (1992): Effect of Ganoderma polysaccharides on T cell Subpopulations and production of interleukin 2 in mixed lymphocyte Response. Acta Pharmaceut. Sin. 27: 331-335.

10. Morigwa, A, Kitabatake, K, Fujimoto, Y and Iikekawa, N (1986): chemical and pharmaceutical Bulletin 34(7): 3025-8.

11. Ofodile, L.N., Uma, N.U., Kokubun, T., Ogundipe, O.T., Simmonds, M.S.J. (2005):Antimicrobial activity of Some Ganoderma species from Nigeria. Phytother. Res. 19, 310-313.

12. Lorke D. (1983): A new approach to practical acute toxicity testing.Arch Toxicology. 54:275-287.

13. Chang, H.W., Baek, N.I., Lee, E.H., Kang, J.H., Cho, S.W. and Chois, Y. (2001): The stimulatory effect of Ganoderma lucidum and phellinus linteus on the antioxidant enzyme catalase. Journal of Biochemistry and Molecular Biology, 34(2): 144-149.

14. Duncan C; Knapp G and Miller, M C.(1977): Test of hypotheses in population Means, In: Introductory Biostatistics for Health sciences, john Wiley and son, Inc. N. pp71-76.

15. Lin JM, Lin CC, Chen MF, Ujiie T, Takada A (1995). Radical scavenger and antihepatotoxic activity of Garnodema formosanumu, Garnoderma lucidum and neo-japonicum Ethopharmcol. 47: 33-41

16. Lin JM, Lin CC, Chiu HF, Yang JJ, Lee SC (1993). Evaluation of the anti-inflammatory and Liver-protective effects of anoectochilus formosanum, garnoderma lucidum and gynostemma pentaphyllum in rats. Am. Chin. Med 21: 59-69

17. Eo SK, Kim YS, Lee CK, Han SS (2000). Possible mode of antiviral activity of acidic protein bound polysaccharide isolated from Garnoderm lucidum on herps simplex Viruses. J. Ethnopharmacol. 72:475-481.

18. El-Mekkawy S, Messelhy MR, Nakamura N, Tezuka Y, Hattori M, Kakiuchi N,Shimotohno K, Kawahata T, Otake T (1998). Anti- HIV-1 and anti HIV-1 protease substance from Garnoderma lucidum. Phytochemistry 49: 1651-1657.

19. Wang SY, Hsu ML, Hsu HC Tzeng CH, Lee SS, Shiao MS Ho CK (1997). The anti-tumor effect of Garnoderma lucidum is mediated by cytokines released from activated macrophages and T lymphocytes. Int.J. Cancer 70: 699-705.

20. Yoon SY, Eo SK, Kim YS, Lee CK Han SS (1994). Antimicrobial activity of Garnoderma lucidum extracts alone and in combination with some antibiotics. Arch. Pharm. Res. 17:438-442. 